\title{
BUILDING CANVAS STRATEGY FOR INTEGRATED TOURISM AREA AND BENCHMARK: BLUE OCEAN STRATEGY APPROACH
}

\author{
Utami, Christina Whidya, Hendro Susanto, Fanny Septina, \\ Yoseva M. Pujirahayu, M. Nurdin R. \\ Universitas Ciputra Surabaya
}

\begin{abstract}
This research aims to identify tourism factors of eliminate, reduce, raise, and create (ERRC) in indicating the characteristics of Blue Ocean Strategy (BOS) in order to revitalize the development of Kenjeran tourism area, Surabaya by taking into account aspects of education, local economic improvement, and environmental conservation. The research methodology is based on descriptive approach through analyzing the strength, weakness, opportunities, and threats (SWOT) to find the key success factors, the industry benchmarks, and the tourism market agents in order to understand the ERRC and to set a canvas strategy. The result shows that Revitalization is done by Eliminating Aspect of Sustainable Environment including environmental pollution, abrasion, and unregulated zone. Reducing Aspect of Attractions includes: a shift in local culture and focus on shopping area. Factors that should be focused on are Aspects of Accessibility and Empowerment, including tourism facilities, and community capacity development. Whereas elements that should be created are included in Aspect of Tourism Industry, including pattern of partnership and community development. The novelties of this research is in the use of Blue Ocean Strategy via a 4-step approach: Eliminate, Reduce, Raise, and Create (ERRC) to revitalize an integrated tourist area.
\end{abstract}

Keywords: eliminate, reduce,, raise, and create (ERRC); canvas strategy; blue ocean strategy.

\section{INTRODUCTION}

Surabaya city is beginning to pioneer and organize to become a tourist destination city. Surabaya city consists of 31 districts and 163 villages; among the

\footnotetext{
"Corresponding Author.

e-mail:whidyautami@ciputra.ac.id
} 
districts in Surabaya is the Kenjeran district. In Kenjeran district, there are nautical tourist destinations located northeast of Surabaya. Right now, the development of tourism in Kenjeran has slowed down and is contrary of the development of Surabaya's tourism in other sectors (RDTR Tambak Wedi, 2017). To optimize Kenjeran's tourism development, the city is combining and integrating a number of objects and tourist attractions that exist within the area. Tourism is not only a source of foreign exchange but is also a factor in determining the location of industry in the development of the poor areas' natural resources, thus making the development of tourism as a way to advance economic areas that are less developed as a result of the lack of natural resources. Tourism is an economic activity seen from the two sides of demand and supply. The success in the development of tourism in an area highly depends on the ability of planners in integrating the two sides to be evenly matched in a tourism development plan (Wahyudi, 2018).

The population data of Kenjeran district in percentage showed that $50 \%$ of the population is still dominated by the poor. The measure of the high, medium, and low socioeconomic population in Kenjeran district can be identified by the level of income. However, the measurements are as follows: a) the level of income gained by high income population is $<\mathrm{Rp} 3.000 .000, \mathrm{~b})$ the level of income of medium income population is between $\mathrm{Rp} 1.000 .000-\mathrm{Rp}$ 2.000.000, and c) the level of income that is gained by low income population is $<\mathrm{Rp}$ 1.000.000. Meanwhile, the population of Kenjeran district based on level the of education is dominated by primary school graduates (40\%). Hence, the opportunity to work as government workers is very low due to the low education level. Based on the demographic above, it shows that the majority of occupation of Kenjeran's population is as traditional fishermen and fish processing. Traditional fishermen in their daily life are always oriented in fulfilling the daily needs, thus the catch is not stored and used to develop a business. Traditional fishermen use traditional technology when fishing and this causes traditional fishermen to lose competition to modern fishermen. The struggle to improve public welfare of fishermen or coastal residents of Kenjeran is not only caused by external factors but more by the internal factors of the population itself. The livelihood from the sea and the coast has been the main source of income. The coastal life has created a long cultural history that cannot be easily changed. This makes the population 
of coastal Kenjeran to lack in their exploration of new ways to improve welfare other than through fishing. Therefore, the socioeconomic characteristic of Kenjeran district's population is rather concerning and requires attention although the economic growth of Surabaya city in 2017 reached 6\% (Zahro, 2017). The public welfare aspect should be a development activity that is oriented toward the citizen by focusing on the aspects of justice, balanced ecosystem, public participation, and if possible, based on the initiative of the local community (Tampubolon, 2016).

According to Wahyudi (2018), there is a correlation between the environmental or ecology condition, socio economic condition, Community sustainability, and Institutional sustainability that need to be considered in integrally developing the coastal area. This highlights the need to make Kenjeran as Surabaya's integrated tourist area to have effect on the increase of surrounding public welfare by maintaining focus on environmental factors. The final result of the development of integrated tourism is increased welfare of the coastal community that hinges their life on natural resources available in coastal areas while simultaneously maintaining the surrounding biological sustainability and ecosystem.

The hospitality environment gradually becomes unstable due to a shift in the complexity of variations in customer demand and purchasing behavior. According to Yeong et al. in Wulandari (2017), important determinants of the complexity of variations in customer demand and purchasing behavior are described by five characteristics of innovation i.e. the relative advantage, compatibility, complexity, trialability, and observability. Moreover, recently both the global natural environment and the economic condition have changed considerably. This has also led to an increased complication in the areas of room capacity management. Based on this literature, the suggested solution is to use the Blue Ocean Strategy approach (BOS) that could integrate the environmental, cultural, and educational aspects in creating a tourist area in Kenjeran, Surabaya.

Which of the factors need to be eliminated, reduced, raised, and created (ERRC) as strategic characteristics of BOS in order to determine an innovative development model for Kenjeran's integrated tourism area in Surabaya is done by examining the aspects of education, culture, and conservation of the environment. 


\section{LITERATURE REVIEW}

The BOS strategy that has been studied in the area of strategic marketing becomes a chosen strategy that is related with the longevity of an organization in the context of turbulent business environment, including in the tourism industry. BOS shifts the focus from the competition between organizations in a market and reconstructed the market boundaries and creates new customer requests. Kim and Mauborgne (2016) conducted a research on BOS for the last 20 years and have produced a number of studies that demonstrate that creating and implementing strategies in turbulent and hyper competition conditions can mobilize the organization to the next level and in turn increases the effectivity of the business entity. BOS strategies implementation conditions a business entity, in this case, tourism business can play a single part without competitors, is due to the synergy between value and innovation. BOS implements value innovation as a foundation and is created by various strategic steps that produce products or services that is substantially different from other offers. This strategic step also functions to produce high valued products or services that have never existed before, with an affordable price for consumers. In the effort to create innovation, values can be translated with product efficiency cost and creates a higher value for consumers. The canvas strategy, which is used to help translate things from factors that determines within an industry, is the focus in the four-action framework, which is known as eliminate, reduce, raise, and create (ERRC).

According to Shafiq, Muhammad et al., 2017, Innovation Performance is an important factor to gain competitive advantage and reach organizational success. All organizations need to innovate to increase their market share. Kotler dan Keller (2016) stated that marketing management is the art and science of choosing target markets and getting, keeping, and growing customers through delivering and communicating superior customers value. Organizations are motivated to innovate because of internationalization and market competition in order to lead the competitive market, as stated by (Harris et al, 2013). Companies should innovate in systematic ways and apply different strategies to gain competitive advantage (Shafiq \& Tasmin, 2016). An organization's innovation performance is formed via innovation actions, including creating new services, new products, and Innovation involves combining unique skills among partners (Bilgies, 2017). Innovation performance captures unreasonable domains 
of organizational competitive advantage. According to Bilqies (2017), product innovation is seen as the most important way to establish a competitive advantage and to maintain the sustainability of the organization. Organizational performance is known as life ability. Management researchers have recognized that companies can acquire and maintain competitive advantage due to their ability to renew, integrate, and expand existing competencies and develop new capabilities. Product innovation has been seen in this context.

\subsection{Relationship between Blue Ocean Strategy and Innovation Performance}

According to Shafiq, Muhammad et al, 2017, Organizations which have a high risk-taking trend tend to innovate and thus able to increase their competitive advantage as indicated. It was highlighted that there are differences between innovative and non-innovative companies because of the risk of influencing positive innovation. Organizational demands in highly competitive market to keep innovating and communicating means they should adopt specific generic strategies to reach customers' attention and to gain a lead in the market competition (Karabulut, 2015). To support this notion, the main purpose of an organization is not only to be present, but also to develop. Despite the fact that both product and process innovation have positive effects on business performance, the understanding about external market conditions or characteristics in which these two different forms of innovation require are more or less limited. Product innovation does not offer enough competitive advantage to differentiate a successful company (McGrath, 2011). Competitors can easily copy their innovation ideas, hence product life cycles become shorter and competitors from low-wage countries have substantial costs and price advantages. Therefore, companies should consider creating a business model innovation as an opportunity to build sustainable competitive advantage. This action is necessary to evaluate and compare the impact of different strategies on innovation performance (Ezzia \& Jarbouib, 2016). Successful innovation strategies will provide a superior performance because the innovation is valuable for the costumer (Prajogo, 2016), which makes it necessary to understand the relationship between Blue Ocean Strategy and innovation performance. Given all the discussion above, this paper will further explore this topic. The next section will discuss the research framework in detail. 


\section{RESEARCH METHODOLOGY}

The qualitative descriptive method is the research methodology used to identify innovative strategies for Kenjeran's integrated tourism area. The researchers hope that this qualitative descriptive research method would be able to answer the phenomenon that is happening in the organization.

The informants chosen as the research object have to possess the following criteria: knowledgeable in history and the condition of Kenjeran's developing integrated tourism area, an expert in the field of developing integrated tourism area with criteria of understanding the development of the industry, in this case, it is the Head of Perhimpunan Hotel Republik Indonesia (PHRI) of Lombok, the Head of Tourism Department of Mataram, the Head of District Treasury of Mataram, the Head of Cilacap's PHRI, the Head of Tourism Department of Cilacap, the community leader of Pantai Widarapaying, and the Director of PP Development of Suramadu. The expert in environment with the criteria of understanding the development of the environment in this case is: Ecoton organization that moves in the field of marine and river systems. This research will be conducted at Kenjeran's integrated tourism area within an 8 month period, from April to November of 2018.

The data analysis used to assess the condition of Kenjeran's integrated tourism areas is the SWOT analysis. Firstly, the researchers will transfer the research object's condition into the SWOT table by conducting in-depth interviews with the informants regarding the business model. Secondly, conclusion will be drawn from the results of the analysis of each column components: strength, weakness, opportunity and threat. Thirdly, after the SWOT scheme is complete, the researcher will conduct interviews with each informant who are willing to be interviewed and will be asked to provide information on interview draft that has been prepared as well as the other important factors related to the development of the integrated tourism area. Fourthly, according to BOS, there are 2 steps that needs to be completed in the process of analyzing BOS, which are: creating a canvas strategy which analyses the condition of Kenjeran's tourism and comparing it with the integrated tourism area in Lombok and Cilacap. If the value in the curve illustrates a crossing point between benchmarks, then there needs to be a fundamental change in canvas strategies to find alternatives by 
implementing focus and innovative strategies. The comparison between Kenjeran's tourism area and Lombok and Cilacap's integrated tourism area is obtained from the assessment of the interviewee with truthful information. In the fifth step, the curve point value on Kenjeran integrated tourism area's canvas strategy and the competitors tend to have a crossing point, hence a change of strategy for business model needs to be done. Creating a four-action framework to generate a new curve can make these changes. The factors used to generate a curve with new values consist of: 1) eliminate (which factors are directly received by the industry, hence the need to be eliminated?), 2) reduce (which factors that are best to be reduced below the industry standard?), 3) raise (which factors are best to be raised above the industry standard, and 4) create (which factors that does not exist in the industry and needs to be created?). Lastly, the researcher will conclude the results of the analysis in the ERRC schema to plan innovative strategies in order for the business to survive.

\section{DISCUSSION}

\subsection{SWOT Analysis}

The initial stage of the SWOT analysis is about determining the measure of the score of IFAS and EFAS factors. The calculation of these internal factors and external factors scores are shown in the tables below:

Table 1 The Calculated Result of Internal Factor Analysis Strategy (IFAS)

\begin{tabular}{|c|c|c|c|c|}
\hline No. & Internal Strategy Factors & Weight & Value & Score \\
\hline & Strengths & & & \\
\hline 1 & $\begin{array}{l}\text { Surabaya city does not possess alternative coastal } \\
\text { tourism }\end{array}$ & 0.05 & 4 & 0.2 \\
\hline 2 & $\begin{array}{l}\text { Local seafood restaurants in Kenjeran beach are easily } \\
\text { found }\end{array}$ & 0.025 & 4 & 0.1 \\
\hline 3 & Easily accessible roads from the land & 0.05 & 4 & 0.2 \\
\hline 4 & $\begin{array}{l}\text { Tourist facilities at the coastal tourism area are } \\
\text { relatively complete }\end{array}$ & 0.025 & 3 & 0.075 \\
\hline 5 & $\begin{array}{l}\text { Majority of the population's livelihood are fishermen } \\
\text { and food or craft traders }\end{array}$ & 0.05 & 3 & 0.15 \\
\hline 6 & $\begin{array}{l}\text { Kenjeran's coastal tourism is able to increase the } \\
\text { income of the local community }\end{array}$ & 0.05 & 3 & 0.15 \\
\hline 7 & $\begin{array}{l}\text { Kenjeran beach has a sloping beach that stretches along } \\
\text { the road }\end{array}$ & 0.05 & 2 & 0.1 \\
\hline
\end{tabular}




\begin{tabular}{|c|c|c|c|c|}
\hline 8 & $\begin{array}{l}\text { The beach location is shielded by Madura, hence there } \\
\text { are no big waves }\end{array}$ & 0.025 & 3 & 0.075 \\
\hline \multirow[t]{2}{*}{9} & $\begin{array}{l}\text { The appearance of sand islands has the potential to } \\
\text { increase tourist destination at Kenjeran's coastal area }\end{array}$ & 0.025 & 2 & 0.05 \\
\hline & Weaknesses & & & \\
\hline 1 & $\begin{array}{l}\text { Tourist facilities at the beach don't function properly } \\
\text { and are not optimal due to lack of maintenance }\end{array}$ & 0.05 & 4 & 0.2 \\
\hline 2 & $\begin{array}{l}\text { The community's lack of awareness to maintain clean } \\
\text { environment }\end{array}$ & 0.05 & 4 & 0.2 \\
\hline 3 & $\begin{array}{l}\text { The overall lack of promotion of coastal tourist } \\
\text { destinations }\end{array}$ & 0.05 & 4 & 0.2 \\
\hline 4 & $\begin{array}{l}\text { Undeveloped potential of other coastal tourist } \\
\text { attractions }\end{array}$ & 0.025 & 3 & 0.075 \\
\hline 5 & The absence of local coastal tourist attraction & 0.05 & 3 & 0.15 \\
\hline 6 & $\begin{array}{l}\text { The local government involvement in developing } \\
\text { Kenjeran coastal beach is not optimized }\end{array}$ & 0.025 & 3 & 0.075 \\
\hline 7 & Promotion of Kenjeran coastal beach is not optimized & 0.05 & 2 & 0.1 \\
\hline 8 & $\begin{array}{l}\text { Absence of environmental awareness community } \\
\text { involved in empowering the community around } \\
\text { Kenjeran's coastal area }\end{array}$ & 0.05 & 2 & 0.1 \\
\hline 9 & $\begin{array}{l}\text { The internal tourism human resource and the tourism } \\
\text { management of Kenjeran coast have not met the } \\
\text { qualifications, i.e. level of education and skills }\end{array}$ & 0.05 & 3 & 0.15 \\
\hline 10 & Lack of security & 0.025 & 2 & 0.05 \\
\hline 11 & $\begin{array}{l}\text { Layout of the zone location of recreation for souvenir/ } \\
\text { crafts/food merchants is not yet organized and managed }\end{array}$ & 0.025 & 2 & 0.05 \\
\hline 12 & $\begin{array}{l}\text { Kenjeran beach as the reservoir of many rivers in } \\
\text { Surabaya is still highly polluted }\end{array}$ & 0.05 & 3 & 0.15 \\
\hline 13 & $\begin{array}{l}\text { The biota in Kenjeran beach is contaminated with } \\
\text { heavy metals }(\mathrm{Cd}, \mathrm{Cr}, \mathrm{Cu} \text {, and } \mathrm{Pb})\end{array}$ & 0.025 & 3 & 0.075 \\
\hline 14 & $\begin{array}{l}\text { The negative impact of sand island to the environment } \\
\text { of Kenjeran coastal area }\end{array}$ & 0.025 & 4 & 0.1 \\
\hline \multirow[t]{2}{*}{15} & $\begin{array}{l}\text { The development of Surabaya city is focused on service } \\
\text { and business }\end{array}$ & 0.1 & 4 & 0.4 \\
\hline & Total & & & 3.175 \\
\hline
\end{tabular}

Table 2 The Calculated Results of External Factor Analysis Strategic (EFAS)

\begin{tabular}{cllcc}
\hline \multicolumn{1}{c}{ Opportunities } & & & \\
\hline No. & \multicolumn{1}{c}{ Factors of Internal Strategies } & Weight & Value & Score \\
\hline 1 & There are many policies in coastal tourism development & 0.05 & 4 & 0.2 \\
\hline 2 & $\begin{array}{l}\text { One of the developments of nature-oriented tourism field } \\
\text { is the coastal area }\end{array}$ & 0.075 & 4 & 0.3 \\
\hline 3 & The level of tourist enthusiasm to visit coastal area & 0.05 & 2 & 0.1 \\
\hline 4 & Tourist information is easily accessible through the internet & 0.05 & 2 & 0.1 \\
\hline 5 & Numerous tourist agencies & 0.025 & 2 & 0.05 \\
\hline 6 & The means, infrastructure, and easy access from land & 0.05 & 4 & 0.2 \\
\hline
\end{tabular}


Utami, Christina Whidya, Hendro Susanto, Fanny Septina, Yoseva M. Pujirahayu, M. Nurdin R. / Building Canvas Strategy for Integrated Tourism Area and Benchmark: Blue Ocean Strategy Approach

\begin{tabular}{clccc}
\hline 7 & $\begin{array}{l}\text { Surabaya does not own an alternative coastal tourist } \\
\text { destination }\end{array}$ & 0.05 & 3 & 0.15 \\
\hline 8 & $\begin{array}{l}\text { There are many developers that invest around Kenjeran's } \\
\text { coastal area (Mentari beach/Pakuwon) }\end{array}$ & 0.05 & 4 & 0.2 \\
\hline 9 & Kenpark as one of Kenjeran's tourist icons & 0.025 & 4 & 0.1 \\
\hline 10 & $\begin{array}{l}\text { There is a need for a development partnership between the } \\
\text { local government and private integrated organization }\end{array}$ & 0.05 & 3 & 0.15 \\
\hline & Threats & & & \\
\hline 1 & The utilization of the coastal area based on several sectors \\
\hline 2 & $\begin{array}{l}\text { The local culture could shift due to the interaction between } \\
\text { the local community and tourists }\end{array}$ & 0.025 & 4 & 0.1 \\
\hline 3 & Environmental pollution in the coastal area & 0.15 & 4 & 0.3 \\
\hline 4 & Impact of abrasion and mud sedimentation & 0.05 & 3 & 0.15 \\
\hline 5 & $\begin{array}{l}\text { The lack of interest from private investors on coastal } \\
\text { tourism }\end{array}$ & 0.05 & 2 & 0.1 \\
\hline 6 & $\begin{array}{l}\text { Local community does not fully support the development } \\
\text { of Kenjeran's coastal area }\end{array}$ & 0.05 & 3 & 0.15 \\
\hline 7 & Reclamation plan of Kenjeran beach & 0.05 & 2 & 0.1 \\
\hline & Total & 1 & & 3.05 \\
\hline & $\quad$ & & \\
\hline
\end{tabular}

The tables above illustrate that the result of internal factor (3.175) is greater than the external factor (3.05). This shows the need of developing at internal level to improve the tourism of Kenjeran coastal area in Surabaya compared to the external factors.

\subsection{Benchmark Analysis}

Kenjeran tourism area is based on two benchmarks, which are Lombok and Cilacap tourism area. From the observation conducted by the researchers, the result shows that the benchmarks in Lombok and Cilacap share similarities and advantages. This will be used as reference to investigate strategies that may help Kenjeran tourism area to develop its business.

\subsubsection{Determining Key Success Factor (KSF) for the Development of Kenjeran Beach Coast}

According to SWOT analysis and Benchmarks, as well as using information from the literature review, there are several key discussions that have the potential to define the Key Success Factor (KSF) for the development of Kenjeran beach coast, including: 
1. Aspect of attraction including diversity of tourism activities, visitor management, and aspect of tourism awareness.

2. Aspect of amenities which includes infrastructure and facilities as well as business standards, including: public infrastructure, public facilities, and tourism, such as: public infrastructure (electricity, water, telecommunication, waste management), public facilities (security, banking-financing, business, health, sanitation and hygiene, special consideration for people with physical disability, young children, and elderly, parking, and places of worship), tourism facilities (accommodations, restaurants, tourism information and service desks, immigration services and e-tourism kiosks, tourism police and tourist task units, souvenir shops, signs of directions, signs of tourism areas, and landscape formations).

3. Aspect of tourism accessibility that include: transportation (modes of public transportation, rivers, lakes and the crossing paths, marine transportations and railways), transportation infrastructure (seaports, airports, railway stations), and transportation system (route information, schedule, ICT, ease to reserve transportation).

4. Aspect of environmental sustainability that involve: strengthening of government regulation regarding to environmental conservation as well as responsibilities to take care of the nature and the culture.

5. Aspect of community empowerment that include: tourism awareness, developing the community's capacity to develop their economic value through rising awareness on education and environmental concerns.

6. Aspect of marketing the tourism area which involve: developing the market of tourism, tourist image development, tourism marketing partnership development, and promotion development regarding the tourism area.

7. Aspect of tourism industry, which include: business partnership, business credibility, competitiveness of tourism products, and development of human resources in tourism.

\subsection{Analysis and Discussion of Canvas Strategies}

Based on the interview and the observation that was conducted by researchers to the 12 informants, SWOT analysis, benchmark, and literature review, there 
Utami, Christina Whidya, Hendro Susanto, Fanny Septina, Yoseva M. Pujirahayu, M. Nurdin R. / Building Canvas Strategy for Integrated Tourism Area and Benchmark: Blue Ocean Strategy Approach

are 7 (seven) determining factors that illustrate the canvas strategies in Kenjeran tourism area. Those factors are attraction, amenities, accessibilities, environment suitability, community empowerment, tourism marketing, and aspect of tourism industry.

\subsection{Analysis and discussion of the Four-Step Framework}

According to Kim and Mauborgne (2016), the factors that need to be carried out to obtain new curve of value consist of:

1. What factors are directly received by the industry, so that it need to be abolished?

2. What factors should be reduced to below the industry standards?

3. What factors should be improved to above the industry standard?

4. What factors have never existed in the industry that need to be developed? The result of the analysis is summarized as follow:

Table 3 ERRC Plan for Kenjeran Tourism Area

\begin{tabular}{|c|c|}
\hline Eliminate & Raise \\
\hline $\begin{array}{l}\text { Unregulated layout of zone for } \\
\text { souvenirs/arts/food traders (W11) }\end{array}$ & $\begin{array}{l}\text { Surabaya does not have other alternatives of beach } \\
\text { tourism area. (S1) }\end{array}$ \\
\hline Lack of security system (W10) & $\begin{array}{l}\text { Tourism facilities in Kenjeran tourism area is } \\
\text { relatively complete (S4) }\end{array}$ \\
\hline $\begin{array}{l}\text { The marine life in Kenjeran is contaminated with } \\
\text { heavy metals, such as } \mathrm{Cd}, \mathrm{Cr}, \mathrm{Cu} \text {, and } \mathrm{Pb}(\mathrm{W} 13)\end{array}$ & $\begin{array}{l}\text { It is easy to find restaurants which uses fishery } \\
\text { products from the Kenjeran beach (S2) }\end{array}$ \\
\hline Environmental pollution in coastal area (T3) & Accessible road access from land (S3) \\
\hline \multirow[t]{9}{*}{$\begin{array}{l}\text { Impact of sludge abrasion and sedimentation } \\
\text { (T4) }\end{array}$} & $\begin{array}{l}\text { Facilities, infrastructure and easy access via land } \\
\text { (O6) }\end{array}$ \\
\hline & $\begin{array}{l}\text { A lot of government policies in developing coastal } \\
\text { tourism (O1) }\end{array}$ \\
\hline & $\begin{array}{l}\text { The amount of tourists' interest to visit coastal } \\
\text { tourism areas (O3) }\end{array}$ \\
\hline & $\begin{array}{l}\text { Kenjeran has a sloping beach that extends along } \\
\text { the road (S7) }\end{array}$ \\
\hline & $\begin{array}{l}\text { Lack of public awareness to keep the cleanliness of } \\
\text { the beach (W1) }\end{array}$ \\
\hline & $\begin{array}{l}\text { The livelihood of most residents is fisherman and } \\
\text { food/craft traders (S5) }\end{array}$ \\
\hline & $\begin{array}{l}\text { The surrounding community does not support the } \\
\text { development of coastal tourism in Kenjeran (T6) }\end{array}$ \\
\hline & $\begin{array}{l}\text { In overall there is a lack of promotion in the } \\
\text { coastal tourism area (W3) }\end{array}$ \\
\hline & $\begin{array}{l}\text { Promotion of the Kenjeran coastline is not yet } \\
\text { optimal (W7) }\end{array}$ \\
\hline
\end{tabular}


Kenpark serves as one of the Kenjeran tourism icons (O9)

The internal human resources of Kenjeran tourism and the tourism management is still not qualified enough, for example the level of education and skills (W9)

\begin{tabular}{ll}
\hline \multicolumn{1}{c}{ Reduce } & \multicolumn{1}{c}{ Create } \\
\hline $\begin{array}{l}\text { The involvement of the city government in the } \\
\text { Kenjeran coastal development is still not optimal } \\
\text { (W6) }\end{array}$ & $\begin{array}{l}\text { Have information available on the internet that } \\
\text { easily accessible by people (O4) }\end{array}$ \\
\hline $\begin{array}{l}\text { The focus of Surabaya city development is on } \\
\text { service and trade and focus on shopping area } \\
\text { (W15) }\end{array}$ & $\begin{array}{l}\text { The development of tourism area that leads to } \\
\text { nature, one of them is the coastal area (O2) }\end{array}$ \\
$\begin{array}{l}\text { Kenjeran beach is an estuary spot for several } \\
\text { rivers in Surabaya that has high level of pollution } \\
\text { (W12) }\end{array}$ & $\begin{array}{l}\text { Madura shields the location of the beach; thus, it } \\
\text { does not have a big wave (S8) }\end{array}$ \\
\hline $\begin{array}{l}\text { Negative impacts on the environment due to the } \\
\text { existence of Pasir island in Kenjeran beach coast } \\
\text { (W14) }\end{array}$ & $\begin{array}{l}\text { The emergence of Pasir Island serving as a } \\
\text { potential tourism area in Kenjeran (S9) }\end{array}$ \\
\hline $\begin{array}{l}\text { The local culture can change due to the } \\
\text { interaction of local communities with the tourists } \\
\text { (T2) }\end{array}$ & $\begin{array}{l}\text { There is no community of environmental observers } \\
\text { involved in the program to empower the } \\
\text { community around the coast of Kenjeran (W8) }\end{array}$ \\
\hline $\begin{array}{l}\text { Many developers invest in Kenjeran coastal area } \\
\text { (Pantai Mentari/ Pakuwon) (O8) }\end{array}$ & $\begin{array}{l}\text { They should have a management cooperation } \\
\text { between the local government and an integrated } \\
\text { private sector (O10) }\end{array}$ \\
\hline
\end{tabular}

From the schema above, a canvas strategy will be formed for the company. Thus, the result can be formed into different classifications. Factors that need to be eliminated are environmental pollution (T3), abrasion (T4), and unregulated zone (W11) which are classified as aspects of sustainable environment. While the elements that should be reduced include: shift in local culture (T2) and the focus on shopping area(W15) that are classified as aspects of attractions. Factors that must be reduced include: tourism faculties (S4), community capacity development (S5), which are classified as aspects of accessibility and empowerment. Whereas elements that should be created are pattern of partnership (O10) and Community development (w8) which are classified as aspects of tourism industry. 
Utami, Christina Whidya, Hendro Susanto, Fanny Septina, Yoseva M. Pujirahayu, M. Nurdin R. / Building Canvas Strategy for Integrated Tourism Area and Benchmark: Blue Ocean Strategy Approach

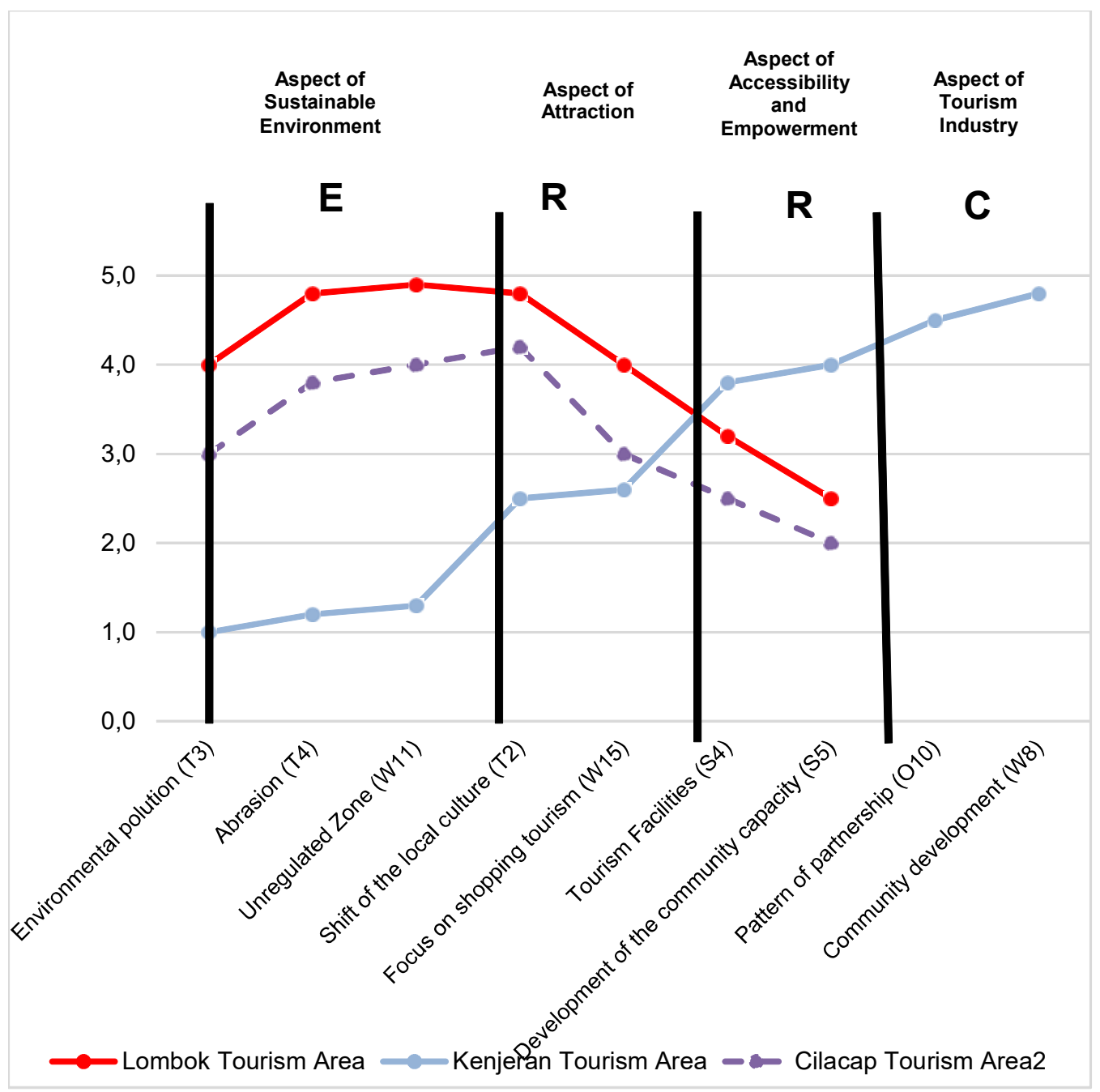

Figure 1 Canvas Strategy for Integrated Tourism Area vs Benchmark

Source: Data processed by the researchers, 2018

\section{MANAGERIAL IMPLICATION}

\subsection{Develop Trade-off Value-cost in the Kenjeran Tourism Area}

Another basic concept of BOS involves the creation of a trade-off value-cost. This study found that there are two factors that are created in the aspect of tourism, which are: adjusting to the pattern of partnership and community 
development. Traditionally, Kenjeran tourism area coordinates with wholesalers and the Surabaya government to develop the tourist area, as well as to improve aspects of environmental preservation and empowerment of the surrounding community. This approach does not only create a cost-trade-off, but also provides new offers for the tourists who potentially will visit the tourism area. This approach also consolidates and utilizes the existence of the communities and the related stakeholders, such as: making negotiations with several agencies to make tour packages in order to take advantage of the costs and effects of marketing. In addition, collaborating with the local traders, local government, and the communities will enable them to integrate Kenjeran tourism area to align the entire system of activities with strategic differentiation choices. This concept is an example of an implementation of BOS (Kim and Mauborgne, 2005). In relation to the concept of partnership and community development, the finding of this research shows a number of strategic alliances (for example, collaboration across industries with medical services, community of environmental observers and recreational entities, and formation of partnership with PHRI Hotels Association of the Republic of Indonesia) to implement BOS with aspects of product differentiation and trade aspects of low-off coast. A number of literature reviews (e.g. Chathoth and Olsen 2003; Reid et al., 2008) have noted that joint programs and activities with the communities can facilitate continuous benefits for the Kenjeran integrated tourism area.

\subsection{Market re-Segmentation and re-Branding}

According to Abdillah (2016) a number of literatures indicated that tourists' interest in coastal areas appear to fluctuate and the pattern of their tourists' demand sometimes are unpredictable. Variation in tourists' demand appears on the seasonal patterns, for example on school holidays. Therefore, managing the capacity of the space is a significant factor in the domain of strategic operational management in integrated tourism areas (Richard, 2016). Robert and Richard (2016) described capacity management as a way to provide enough space to meet visitors' demand. Tourism businesses must be aware of these complex variations of demand and should set a target market in different seasons to maximize the use of capacity. Modifying market segmentation can be done through positioning 
and rebranding. The findings indicate that stakeholders expect Kenjeran tourism place to rebrand their name by eliminating elements of environmental pollution, abrasion, and unorganized tourist zone, as well as reducing factors of local culture that continues to change and focus on shopping area.

Ismayanti (2016) suggested that rebranding will contribute to an on-going success and consistency to sustain the management of the coastal tourism area. This study shows that many tourism managers have implemented re-branding strategy as a marketing strategy. In the end, building brand affiliation will increase stakeholders' attention and make a "value" as indicated by Bilqies (2017). Determining rebranding action cannot be separated from the innovation plan that has been arranged. Companies must innovate systematically through several strategies in order to have a lead in the market competition and organizational innovation is found through innovation action, such as new services, new products, and the number of partners (Shafiq \& Tasmin, 2016).

\section{CONCLUSION}

a. The IFAS and EFAS analysis shows the need to develop the internal factor to improve the tourist attraction in Kenjeran, Surabaya rather than focusing on the external factor only. Thus, internal stakeholders, such as the local government, holds an important role during the revitalization process of the Kenjeran coastal area.

b. Based on the process of Blue Ocean Strategy via ERRC (Eliminate, Reduce, Raise, and Create), the research found that there are factors that should be eliminated, including environmental pollution, abrasion, and unregulated zone which is classified as aspects of sustainable environment. While the elements that should be reduced include: shift in local culture and the focus on shopping area that are classified as aspects of attractions. Factors that must be raise include: tourism facilities, community capacity development, which are classified as aspects of accessibility and empowerment. Whereas elements that should be created are pattern of partnership and Community development that is classified as aspects of tourism industry.

c. There are two managerial implications, which are: to develop a trade-off value-cost in Kenjeran tourism attraction and re-segmentation and re-brand- 
ing of the market. Developing trade-off value-cost in Kenjeran should focus on two factors of 'create' in tourism industry, which are: to adjust the pattern of partnership and to develop the community. One the other hand, market resegmentation and rebranding can be done by eliminating elements of environmental pollution, abrasion, and unorganized tourist zones, as well as reducing factors of change in the local culture and focus on shopping area.

d. Rebranding contributes to the success and the consistency of sustainability of the coastal tourism management, as long as it followed by an overall innovation approach. This action is in line with a suggestion by (Shafiq \& Tasmin, 2016) who said that companies must innovate systematically through several strategies in order to have competitive advantage.

e. Conducting Blue Ocean Strategy through ERRC approach is able to answer the strategic plan of developing an integrated tourism area in Kenjeran, Surabaya, Indonesia.

Acknowledgement: Funding for this research is Indonesian science institutions (Lembaga Ilmu Pengetahuan Indonesia) in the demand driven research grant program.

\section{REFERENCE}

Abdillah. (2016). Pengembangan Wisata Bahari di Pesisir Pantai Teluk Lampung. Jurnal Destinasi Kepariwisataan Indonesia. Vol. 1, No. 1, p 45-66.

Bilgies, A. (2017). Keunggulan Kompetitif yang dalam Menciptakan Inovasi untuk Kewirausahaan Strategis. Journal An-Nisbah Universitas Islam Darul Ulum Lamongan. Vol. 03, No. 02.

Chathoth, P.K. and Olsen, M.D. (2003), "Strategic alliances: a hospitality industry perspective". International Journal of Hospitality Management, Vol. 22 No. 4, pp. 419-34.

Ezzia, F., \& Jarbouib, A. (2016). Afecta la estrategia de innovación al rendimiento financiero, social y ambiental?. Journal of Economics, Finance and Administrative Science, 21(40), 14-24. 
Richard B. Chase, Robert. (2016). Management Operasi dan Rantai Pasokan, Edisi 14. Jakarta: Salemba Empat.

Harris, R., McAdam, R., McCausland, I., \& Reid, R. (2013). Levels of innovation within SMEs in peripheral regions: the role of business improvement initiatives. Journal of Small Business and Enterprise Development, 20(1), $102-124$.

Ismayanti. (2016). Pariwisata Berkelanjutan dan Pengembangan Pariwisata Bahari. Retrieved February 1st 2019, http://www.jejakwisata.com/index.php/studies/48-pariwisata-berkelanjutan-dan-pengembangan-pariwisata-bahari.

Karabulut, A. T. (2015). Effects of innovation types on performance of manufacturing firms in Turkey. Procedia-Social and Behavioral Sciences, 195, 13551364.

Kotler, Philip and Kevin Lane Keller. (2016). Marketing Managemen, 15th Edition. Pearson Education, Inc.

McGrath, A. E. (2011). The Open Secret: A New Vision for Natural Theology. John Wiley \& Sons.

Prajogo, D. I. (2016). The strategic fit between innovation strategies and business environment in delivering business performance. International Journal of Production Economics, 171, 241-249.

RPJMD. (2015). Gambaran Umum Kondisi Daerah. Surabaya: RPJMD Kota Surabaya.

Shafiq, M. \& Tasmin, R. (2016). Linking Business Strategy with Organizational Innovation. Innovation and Management.

Tampubolon, D. (2016). Analisis Dampak Pemekaran Daerah Ditinjau dari Aspek Percepatan Pertumbuhan Ekonomi dan Peningkatan Kualitas Pelayanan Publik (Studi Pemekaran Kabupaten Kepulauan Meranti dari Kabupaten Bengkalis). Jurnal Online Mahasiswa Fakultas Ekonomi, 843-857.

Wahyudi, Isa. (2018). Konsep Pengembangan Wisata. Malang: Inspire Consulting. Wulandari, D. (2017). The Effect of Product Innovation (Relative Advantage, Compatibility, and Complexity) towards Intention to Use Mobile Banking BRI (A Study on $3 \mathrm{Kg}$ LPG Agent in Bandar Lampung). Universitas Lampung, Bandar Lampung.

Wedi, P. K. (2008-2017). Rencana Detail Teknik Ruang Kota Tambak Wedi. Tambak Wedi: Pemerintah Kota Tambak Wedi. 
Review of Management and Entrepreneurship

Volume 05, Number 01, April 2021

Reid, L.J., Smith, S.L.J. and McCloskey, R. (2008). “The effectiveness of regional marketing alliances: a case study of the Atlantic Canada tourism partnership 2000-2006". Tourism Management, Vol. 29, No. 3, pp. 581-593. 